\title{
Removal of PCR inhibitors from soil DNA by chemical flocculation
}

\author{
Michael D. Braid ${ }^{\text {a }}$, Laura M. Daniels ${ }^{\mathrm{b}}$, Christopher L. Kitts ${ }^{\mathrm{c}}$ \\ ${ }^{a}$ Ciphergen Biosystems, Incorporated, 6611 Dumbarton Circle, Fremont, CA 94555, USA \\ ${ }^{\mathrm{b}}$ Avian Developmental Genetics Laboratory, Department of Animal Science, University of California, Davis, CA 95616-8521, USA \\ ${ }^{\mathrm{c}}$ Environmental Biotechnology Institute, California Polytechnic State University, San Luis Obispo, CA 93407, USA
}

\begin{abstract}
Extracting high-purity DNA directly from soil has become essential for the study of microorganisms in environmental samples. However, many soils contain compounds that inhibit enzymes involved in manipulating DNA. In this study, chemical flocculation using multivalent cations was investigated as a potential method for eliminating soil-based inhibitors during the extraction process. The addition of $\mathrm{AlNH}_{4}\left(\mathrm{SO}_{4}\right)_{2}$ during extraction significantly reduced the co-purification of PCR inhibitors with minimal loss of DNA yield.
\end{abstract}

Keywords: DNA extraction; DNA purification; PCR inhibition

The use of DNA-based methods has become a standard practice in the study of environmental microbes. These methods are powerful tools for detecting nonculturable organisms and for monitoring introduced microbes in the environment. Such methods rely on PCR to amplify specific genes of interest directly from community DNA. However, working with DNA recovered from soils is often problematic. Many soils contain organic compounds such as humic substances that inhibit restriction endonucleases and Taq DNA polymerase, the key enzyme of PCR (Porteous and Armstrong, 1991; Tsai and Olson, 1992). Humic substances are a major component of soil organic matter. Though the chemical composition is highly complex, these compounds readily co-purify with DNA and are difficult to remove without additional, laborious and time intensive treatments to obtain DNA suitable for PCR (Romanowski et al., 1992; Trevors and van Elsas, 1989).

Many methods have been used to eliminate the humic substances from environmental DNA. Such treatments include polyvinylpolypyrrolidone (PVPP) (Frostegard et al., 1999; Zhou et al., 1995), hexadecyltrimethylammonium bromide (CTAB) (Cho et al., 1996; Malik et al., 1994; Zhou et al., 1995), hydroxyapatite columns (Torsvik, 1980), cesium chloride density centrifugations (Holben et al., 1988; Leff et al., 1995; Lovell and Piceno, 1994; Walia et al., 
1990), ion exchange and size exclusion chromatography (Erb and Wagner-Dobler, 1993; Hurt et al., 2001; Kuske et al., 1998; Leff et al., 1995), and agarose gel electrophoresis followed by excision and DNA extraction from the gel matrix (Malik et al., 1994; More et al., 1994; Zhou et al., 1995). In our experience with a wide variety of soils, the use of PVPP and CTAB has proven unreliable for the removal of inhibitors. Chromatography methods were more reliable, but required additional time, cost and labor. Hydroxyapatite columns and cesium chloride density centrifugations are extremely time-consuming and limit the number of samples that can be analyzed. Additionally, these procedures often result in decreased DNA recovery (Kuske et al., 1998; More et al., 1994; Steffan et al., 1988; Tebbe and Vahjen, 1993; Zhou et al., 1995), possibly eliminating some target templates from more complex communities.

In this investigation, solutions of magnesium chloride $\left(\mathrm{MgCl}_{2}\right)$, ferric chloride $\left(\mathrm{FeCl}_{3}\right)$, calcium chloride $\left(\mathrm{CaCl}_{2}\right)$ and aluminum ammonium sulfate $\left(\mathrm{AlNH}_{4}\left(\mathrm{SO}_{4}\right)_{2}\right)$ were tested for their ability to remove soil-based inhibitors from environmental DNA. The use of multivalent cations has been a standard method for removing suspended organic solids during the purification of drinking water; a process commonly referred to as chemical flocculation. In theory, these chemistries could remove organic inhibitors via flocculation during sample lysis and homogenization, potentially eliminating or reducing the need for additional treatments and the associated sample loss.

Testing soils for inhibitors. DNA was extracted from a collection of 20 soils representing a broad range of soil properties (Table 1). DNA extractions were performed on $0.3 \mathrm{~g}$ of soil using the UltraClean $^{\mathrm{TM}}$ Soil DNA Purification kit (Mo Bio Labs, Solana Beach, CA) following the manufacturer's protocol. In brief, cells were lysed by either a hot detergent/vortex or bead beater method. Hot detergent/vortex lysis was performed by first incubating samples in the manufacturer's lysis solution at $70{ }^{\circ} \mathrm{C}$ for $10 \mathrm{~min}$ followed by mechanical lysis using a Vortex Genie $2^{\circledR}$ mixer (Scientific Industries, Bohemia, NY) with a flat pad. The tubes were secured horizontally with laboratory tape and shaken at maximum speed for $10 \mathrm{~min}$. Bead beater lysis was

Table 1

Characterization and DNA recovery of library soils

\begin{tabular}{|c|c|c|c|c|c|c|c|}
\hline Library soil & $\begin{array}{l}\text { Recovered } \\
\text { DNA, } \mu \mathrm{g} / \mathrm{g}\end{array}$ & $\%$ Carbon & $\%$ Nitrogen & Textural class & $\%$ Sand & $\%$ Silt & $\%$ Clay \\
\hline 9811 & 4.08 & 1.60 & 0.17 & Clay & 16.9 & 37.6 & 45.5 \\
\hline 9307 & 6.20 & 2.17 & 0.15 & Clay & 10.6 & 31.8 & 57.6 \\
\hline 9822 & 6.82 & 2.19 & 0.19 & Clay & 32.0 & 23.3 & 44.7 \\
\hline $9514^{\mathrm{a}}$ & 2.17 & 3.20 & 0.19 & Clay Loam & 23.4 & 46.3 & 30.3 \\
\hline 9824 & 4.91 & 1.31 & 0.14 & Clay Loam & 27.2 & 36.4 & 36.4 \\
\hline 9809 & 8.57 & 1.28 & 0.14 & Clay Loam & 26.0 & 44.8 & 29.3 \\
\hline 503515 & 0.19 & 0.82 & 0.14 & Loam & 50.0 & 35.0 & 15.0 \\
\hline 9506 & 1.00 & 1.56 & 0.11 & Loam & 35.6 & 49.0 & 15.5 \\
\hline $9813^{\mathrm{a}}$ & 5.19 & 1.40 & 0.13 & Loam & 42.4 & 44.3 & 13.3 \\
\hline 9818 & 9.62 & 1.51 & 0.14 & Loam & 38.8 & 41.3 & 19.9 \\
\hline $9308^{\mathrm{a}}$ & 7.36 & 4.66 & 0.33 & Sandy Loam & 67.6 & 27.3 & 5.1 \\
\hline $9834^{\mathrm{a}}$ & 7.96 & 3.91 & 0.14 & Sandy Loam & 62.4 & 29.3 & 8.4 \\
\hline 9020 & 8.89 & 0.81 & 0.10 & Sandy Loam & 64.2 & 25.7 & 10.1 \\
\hline $9310^{\mathrm{a}}$ & 2.17 & 3.51 & 0.31 & Silt Loam & 29.7 & 53.3 & 17.0 \\
\hline 9309 & 4.78 & 0.97 & 0.10 & Silt Loam & 13.7 & 66.5 & 19.8 \\
\hline $9612^{\mathrm{a}}$ & 6.21 & 1.61 & 0.15 & Silt Loam & 25.7 & 54.6 & 19.8 \\
\hline 9305 & 9.84 & 3.85 & 0.33 & Silt Loam & 15.4 & 58.7 & 26.0 \\
\hline 9324 & 20.51 & 1.18 & 0.08 & Silt Loam & 36.8 & 54.1 & 9.2 \\
\hline 9312 & 33.09 & 2.58 & 0.22 & Silt Loam & 15.9 & 66.1 & 18.1 \\
\hline $\mathrm{SJD}^{\mathrm{a}}$ & 12.39 & 19.44 & 1.37 & Histosol & ND & ND & ND \\
\hline
\end{tabular}

ND: not determined.

${ }^{a}$ Soils with inhibition of PCR. 
performed using a Fastprep ${ }^{\circledR}$ instrument (Savant, Farmingdale, NY) at a speed of $4.5 \mathrm{~m} \cdot \mathrm{s}^{-1}$ for $20 \mathrm{~s}$. The soluble fraction was then transferred to another tube where a protein precipitating solution was added. The soluble fraction was passed through a glass fiber filter to collect the DNA, which was cleaned with a salt ethanol wash and then eluted with deionized water. The sample DNA, final volume $50 \mu \mathrm{l}$, was quantified with a $100 \mu 1$ PicoGreen ${ }^{\mathrm{TM}}$ (Molecular Probes, Eugene, OR) assay using a PE LS-50B luminescence spectrophotometer (PE-Biosystems, Foster City, CA) according to the manufacturers' protocols. The fluorescent assay was used due to the ability of humic acids to absorb ultraviolet light at 260 nm (Kuske et al., 1998). DNA yields for the soils varied, ranging from 33 to $0.19 \mu \mathrm{g} / \mathrm{g}$ of soil. The relative purity of the recovered DNA was determined by PCR using $1 \mu \mathrm{l}$ of sample DNA per reaction. Primers homologous to the $16 \mathrm{~S}$ rRNA gene (rDNA) were used for amplification as previously described (Clement et al., 1998). Inhibitors were detected after PCR products were visualized by agarose gel electrophoresis. Inhibition of PCR was defined by one of the following characteristics: a lack of product and primer dimers, or the appearance of primer dimers without a visible PCR product. Seven of the twenty samples tested showed signs of PCR inhibition (Table 1).

Flocculant testing and optimization. The SJD soil displayed the most severe inhibition, no product and no primer dimers, and was used to test flocculation chemistries for the ability to remove inhibitors (Fig. 1). Four multivalent cation solutions were tested in the extraction procedure, either by addition during sample lysis or protein precipitation. Solutions of $200 \mathrm{mM}$ $\mathrm{FeCl}_{3}, \mathrm{MgCl}_{2}, \mathrm{CaCl}_{2}$, and $\mathrm{AlNH}_{4}\left(\mathrm{SO}_{4}\right)_{2}$ were prepared in water and sterilized by vacuum filtration through a $0.2-\mu \mathrm{m}$ membrane. In one set of tubes, $200 \mu \mathrm{l}$ of flocculant was added to the lysis tube following sample loading. The samples were briefly vortexed to incorporate the chemistry just prior to lysis. In another set of tubes, $200 \mu 1$ of reagent was mixed with freshly transferred lysate just prior to protein precipitation. The $\mathrm{MgCl}_{2}$ and $\mathrm{CaCl}_{2}$ reagents displayed yields of DNA comparable to the original, untreated extract when added during either the lysis or precipitation steps. The $\mathrm{FeCl}_{3}$ and $\mathrm{AlNH}_{4}\left(\mathrm{SO}_{4}\right)_{2}$ reagents resulted in a slightly decreased yield of DNA when added during lysis, and no DNA was $\begin{array}{lllllllll}1 & 2 & 3 & 4 & 5 & 6 & 7 & 8 & 9\end{array}$

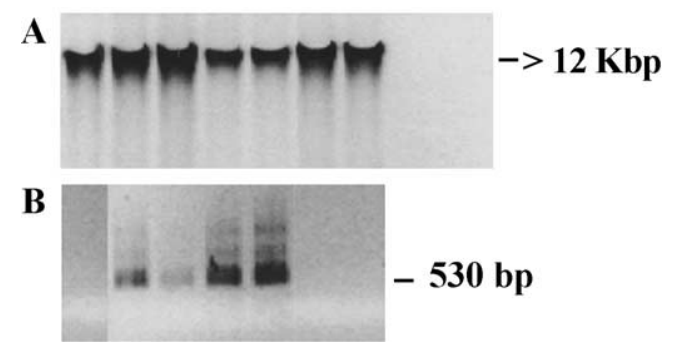

Fig. 1. Composite image displaying agarose gel electrophoresis of extracted DNA and PCR products from flocculant testing. Sample SJD was extracted using the bead beater lysis step in all trials. The upper panels (A) show extracted DNAs. The lower panels (B) display PCR products using the DNA shown above. Samples are: lane 1, untreated; lane 2, $\mathrm{MgCl}_{2}$ at lysis; lane $3, \mathrm{CaCl}_{2}$ at lysis; lane 4, $\mathrm{FeCl}_{3}$ at lysis; lane 5, $\mathrm{AlNH}_{4}\left(\mathrm{SO}_{4}\right)_{2}$ at lysis; lane $6, \mathrm{MgCl}_{2}$ at precipitation; lane $7, \mathrm{CaCl}_{2}$ at precipitation; lane $8, \mathrm{FeCl}_{3}$ at precipitation; lane 9, $\mathrm{AlNH}_{4}\left(\mathrm{SO}_{4}\right)_{2}$ at precipitation. Panel B does not have lanes 8 and 9; no DNA was produced from those samples so no PCR was performed.

recovered after addition during the precipitation step. Analysis of PCR products showed the best amplification in the $\mathrm{FeCl}_{3}$ and $\mathrm{AlNH}_{4}\left(\mathrm{SO}_{4}\right)_{2}$ treated samples (at lysis), with $\mathrm{AlNH}_{4}\left(\mathrm{SO}_{4}\right)_{2}$ providing the most impressive effect (Fig. 1, lanes 4, 5). The $\mathrm{MgCl}_{2}$ and $\mathrm{CaCl}_{2}$ treatments had a minimal effect on PCR inhibitors despite their high yield of DNA. No PCR products were recovered from samples treated during the precipitation step. Based on these results, the addition of $\mathrm{AlNH}_{4}\left(\mathrm{SO}_{4}\right)_{2}$ during lysis was optimized.

Five soils were used to optimize the $\mathrm{AlNH}_{4}\left(\mathrm{SO}_{4}\right)_{2}$ treatment. Concentrations of 50,100, 200 and 400 $\mathrm{mM} \mathrm{AlNH} 4\left(\mathrm{SO}_{4}\right)_{2}$ were tested using hot detergent/ vortex lysis. All samples produced DNA when treated with 50 and $100 \mathrm{mM} \mathrm{AlNH}_{4}\left(\mathrm{SO}_{4}\right)_{2}$. A slight decrease in yield was observed in some of the $100 \mathrm{mM}$ treated samples and a notable decrease in DNA recovery was observed in the $200 \mathrm{mM}$ treated extracts (Fig. 2). No DNA was recovered in the $400 \mathrm{mM} \mathrm{AlNH}{ }_{4}\left(\mathrm{SO}_{4}\right)_{2}$ treated samples (data not shown). PCR results varied among the treatments and soils, however, the $100 \mathrm{mM}$ treated samples consistently amplified (Fig. 2). The SJD soil displayed marked improvement in PCR quality when extracted using 50 and $100 \mathrm{mM}$ $\mathrm{AlNH}_{4}\left(\mathrm{SO}_{4}\right)_{2}$. A significant change in color was noted during processing of the SJD extracts. The untreated sample displayed a dark lysate, with the 


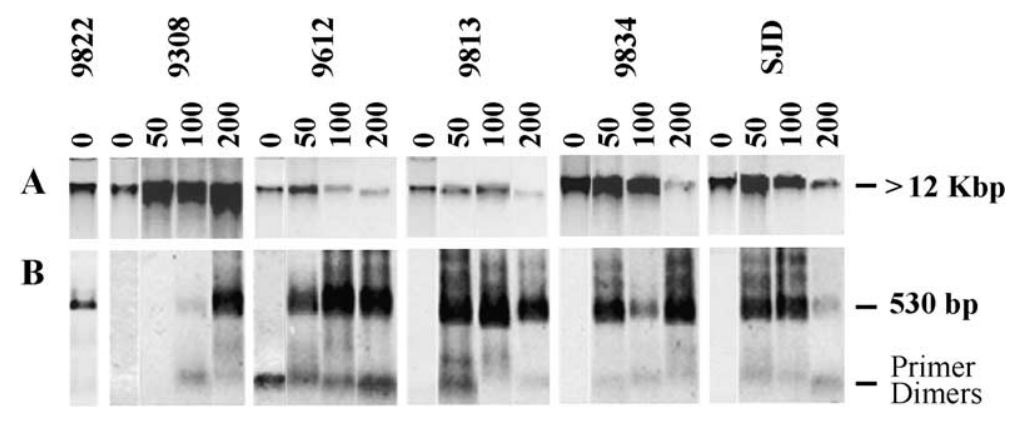

Fig. 2. Composite images from agarose gel electrophoresis of extracted DNA and PCR products from the $\mathrm{AlNH}_{4}\left(\mathrm{SO}_{4}\right)_{2}$ optimization experiment. The upper panels (A) show DNA extracted from the soils. The lower panels (B) show the products of PCR using the DNA shown above. Six library soil samples are shown after extraction by hot detergent/vortex lysis using varying concentrations of $\mathrm{AlNH}_{4}\left(\mathrm{SO}_{4}\right)_{2}$. The concentration of $\mathrm{AlNH}_{4}\left(\mathrm{SO}_{4}\right)_{2}(\mathrm{mM})$ added to the lysis step is shown above each column. Sample names area at the top of each group of extractions. Sample 9822 is an example of soil with no evidence of PCR inhibition.

final product having a slightly brown hue. During extraction with $\mathrm{AlNH}_{4}\left(\mathrm{SO}_{4}\right)_{2}$, the color of the lysate was notably lighter and the purified DNA was clear (data not shown). However, sample 9308 still displayed some inhibition with the $100 \mathrm{mM}$ treatment. The optimal effect for this sample was only achieved when using the $200 \mathrm{mM}$ concentration. Because of the variability in amplification and the general reduction in DNA extraction yield with increasing concentrations of $\mathrm{AlNH}_{4}\left(\mathrm{SO}_{4}\right)_{2}$, the $100 \mathrm{mM}$ concentration was considered optimal and used for additional testing.

To further test the effectiveness of the reagent, six additional samples were processed with and without $\mathrm{AlNH}_{4}\left(\mathrm{SO}_{4}\right)_{2}$ added to the lysis mixture. The samples selected were hypothesized to be problematic based on the environments they represented. Forest soils were selected due to their prolonged coverage by leaf litter. A garden soil was also included in this phase of the study due to its artificial enrichment. All soils yielded DNA after extraction (data not shown). The templates from the garden and creosote soils amplified regardless of treatment. Amplification of untreated DNA from the Pine, Eucalyptus and Oak soils displayed signs of inhibition. However, amplification of $\mathrm{AlNH}_{4}\left(\mathrm{SO}_{4}\right)_{2}$ extracts was unhindered overall, with the CA Pine sample displaying faint product formation (Fig. 3).

The use of $\mathrm{AlNH}_{4}\left(\mathrm{SO}_{4}\right)_{2}$ in the extraction process had no significant effect on preparation times. In addition, chemical flocculation with $\mathrm{AlNH}_{4}\left(\mathrm{SO}_{4}\right)_{2}$ proved a reliable and inexpensive alternative for eliminating or significantly reducing the effects of environmental PCR inhibitors. The $\mathrm{AlNH}_{4}\left(\mathrm{SO}_{4}\right)_{2}$ solution improved the quality of recovered templates to some extent in all cases; PCR compatibility was achieved with most of the problematic samples tested. The slight loss of extracted DNA was one weakness of this method. However, the losses observed appeared minimal and were partially attributed to dilution resulting from the addition of aluminum. The dilution effect can be partially remedied by altering the manufacturer's protocol so that the entire volume of lysate is processed.

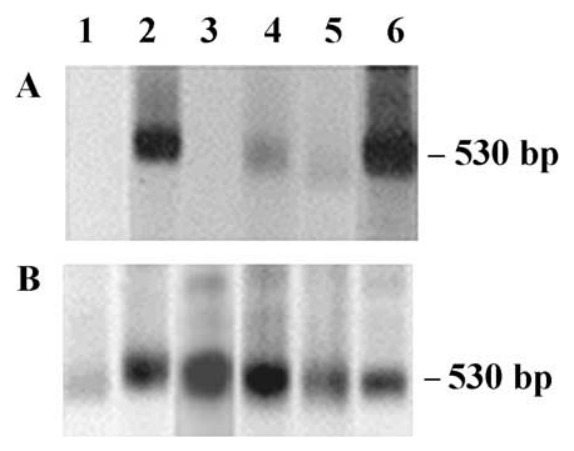

Fig. 3. Composite image representing PCR products from additional soils treated with and without $\mathrm{AlNH}_{4}\left(\mathrm{SO}_{4}\right)_{2}$. Samples were extracted using the bead beater lysis step. The upper panels (A) show PCR products obtained from the untreated soil extracts. The lower panels (B) show PCR products obtained from $100 \mathrm{mM}$ $\mathrm{AlNH}_{4}\left(\mathrm{SO}_{4}\right)_{2}$-treated DNA. Samples are: lane 1, CA Pine; lane 2, Creosote Bush; lane 3, Oak; lane 4, AZ Pine; lane 5, Eucalyptus; lane 6, Garden Soil. 
It is unclear why the $\mathrm{AlNH}_{4}\left(\mathrm{SO}_{4}\right)_{2}$ treatment was able to effectively remove organic inhibitors under optimal conditions while leaving DNA in solution. The aluminum cations may preferentially interact with the open and random structure of inhibitory organic polymers such as humic substances, while the helical structure of DNA may protect it from flocculation. The complete loss of DNA observed when using higher concentrations of $\mathrm{AlNH}_{4}\left(\mathrm{SO}_{4}\right)_{2}$ may be a result of chaotropic effects, possibly inducing DNA binding to siliceous compounds such as clay or diatomaceous particles in the soil. The methods presented here should be appropriate for most soils and may be compatible with other lysis buffers. However, the exact conditions and concentration of $\mathrm{AlNH}_{4}\left(\mathrm{SO}_{4}\right)_{2}$ may require some optimization to achieve the desired effects for any particular soil and buffer combination.

\section{Acknowledgements}

This study was supported by Unocal in a grant for bioremediation studies at the Unocal Guadalupe oil field. We would like to thank Dr. Tom Ruehr for providing the soils samples and textural data. We would also like to gratefully acknowledge LynnDee Althouse (Oyler) and the Schimel Lab at the University of California at Santa Barbara for the carbon and nitrogen analysis of the library soils used in this study.

\section{References}

Cho, J., Lee, D., Cho, Y., Cho, J., Kim, S., 1996. Direct extraction of DNA from soil for amplification of $16 \mathrm{~S}$ rRNA gene sequences by polymerase chain reaction. J. Microbiol. 34 (3), 229-235.

Clement, B.G., Kehl, L.E., DeBord, K.L., Kitts, C.L., 1998. Terminal restriction fragment patterns (TRFPs), a rapid, PCR-based method for the comparison of complex bacterial communities. J. Microbiol. Methods 31, 135-142.

Erb, R.W., Wagner-Dobler, I., 1993. Detection of polychlorinated biphenyl degradation genes in polluted sediments by direct DNA extraction and polymerase chain reaction. Appl. Environ. Microbiol. 59 (12), 4065-4073.

Frostegard, A., Courtois, S., Ramisse, V., Clerc, S., Bernillon, D., Le Gall, F., Jeannin, P., Nesme, X., Simonet, P., 1999. Quanti- fication of bias related to the extraction of DNA directly from soils. Appl. Environ. Microbiol. 65 (12), 5409-5420.

Holben, W.E., Jansson, J.K., Chelm, B.K., Tiedje, J.M., 1988. DNA probe method for the detection of specific microorganisms in the soil bacterial community. Appl. Environ. Microbiol. 54 (3), $703-711$.

Hurt, R.A., Qiu, X., Wu, L., Roh, Y., Palumbo, A.V., Tiedje, J.M., Zhou, J., 2001. Simultaneous recovery of RNA and DNA from soils and sediments. Appl. Environ. Microbiol. 67, 4495-4503.

Kuske, C.R., Banton, K.L., Adorada, D.L., Stark, P.C., Hill, K.K., Jackson, P.J., 1998. Small-scale DNA sample preparation method for field PCR detection of microbial cells and spores in soil. Appl. Environ. Microbiol. 64 (7), 2463-2472.

Leff, L.G., Dana, J.R., McArthur, J.V., Shimkets, L.J., 1995. Comparison of methods of DNA extraction from stream sediments. Appl. Environ. Microbiol. 61 (3), 1141-1143.

Lovell, C.R., Piceno, Y., 1994. Purification of DNA from estuarine sediments. J. Microbiol. Methods 20, 161-174.

Malik, M., Kain, J., Pettigrew, C., Ogram, A., 1994. Purification and molecular analysis of microbial DNA from compost. J. Microbiol. Methods 20, 183-196.

More, M.I., Herrick, J.B., Silva, M.C., Ghiorse, W.C., Madsen, E.L., 1994. Quantitative cell lysis of indigenous microorganisms and rapid extraction of microbial DNA from sediment. Appl. Environ. Microbiol. 60 (5), 1572-1580.

Porteous, L.A., Armstrong, J.L., 1991. Recovery of bulk DNA from soil by a rapid, small-scale extraction method. Curr. Microbiol. 22, 345-348.

Romanowski, G., Lorenz, M.G., Sayler, G., Wackernagel, W., 1992. Persistence of free plasmid DNA in soil monitored by various methods, including a transformation assay. Appl. Environ. Microbiol. 58, 3012-3019.

Steffan, R.J., Goksoyr, J., Bej, A.K., Atlas, R.M., 1988. Recovery of DNA from soils and sediments. Appl. Environ. Microbiol. 54, 2908-2915.

Tebbe, C.C., Vahjen, W., 1993. Interference of humic acids and DNA extracted directly from soil in detection and transformation of recombinant DNA from bacteria and yeast. Appl. Environ. Microbiol. 59, 2657-2665.

Torsvik, V.L., 1980. Isolation of bacterial DNA from soil. Soil Biol. Biochem. 12, 15-21.

Trevors, J.T., van Elsas, J.D., 1989. A review of selected methods in environmental microbial genetics. Can. J. Microbiol. 35, 895-902.

Tsai, Y.L., Olson, B.H., 1992. Detection of low numbers of bacterial cells in soils and sediments by polymerase chain reaction. Appl. Environ. Microbiol. 58, 754-757.

Walia, S., Khan, A., Rosenthal, N., 1990. Construction and applications of DNA probes for detection of polychlorinated biphenyl-degrading genotypes in toxic organic-contaminated soil environments. Appl. Environ. Microbiol. 56 (1), 254-259.

Zhou, J., Bruins, M.A., Tiedje, J.M., 1995. DNA recovery from soils of diverse composition. Appl. Environ. Microbiol. 62, 316-322. 